\title{
Manglende jording i Kambodsja
}

\author{
Gavmilde donorer sørger for at lokalsykehus og helsesentre i fattige strøk av verden mottar avansert diagnos- \\ tisk og terapeutisk utstyr. Brukerne får opplæring i bruk av utstyret, men vedlikehold og kunnskap om farer \\ ved det elektriske anlegget blir ikke ivaretatt. Medisinskteknisk utstyr kan dermed bli en helserisiko for både \\ pasienter og ansatte.
}

Margit Steinholt

margit.steinholt@gmail.com

Tromsø mineskadesenter, som jeg leder, har drevet prehospital traumetrening i Battambang-provinsen i nordvestre Kambodsja siden 1996 (1). Provinsen har ca. én million av landets vel 14 millioner innbyggere, og gjennom tiår med krig og konflikt helt frem til sist i 1990-årene ble landsbygda minelagt og bombet. Situasjonen for sivilbefolkningen er fremdeles svært vanskelig, og i enkelte områder er over $30 \%$ av voksne menn enten enkelt- eller dobbeltamputerte etter mineskader. Det fins ingen trygdeordninger, og i tillegg er det som i andre fattige land en enorm mangel på utdannet helsepersonell (2).

Siden 1996 har tusenvis av legfolk fått opplæring i førstehjelp ved mineskader og andre traumer og ulykker gjennom mineskadesenterets prosjekter. Modellen kalles «chain of survival», og resultatene viser betydelig økt overlevelse etter at opplæringsprogrammene ble iverksatt $(3,4)$. Vår kambodsjanske partnerorganisasjon er Trauma Care Foundation Cambodia (TCF-C). Prosjektene har i all hovedsak vært finansiert gjennom midler fra Utenriksdepartementet, Norad og Norges forskningsråd.

\section{Ustabil strømforsyning}

I 2004 utvidet vi opplæringsprogrammet til også å gjelde fødselskomplikasjoner, og intervensjonen har gitt gode resultater blant både mødre og nyfødte (M. Steinholt, årsmøte Norsk gynekologisk forening, foredrag oktober 2013). For å lette arbeidet for jordmødrene og kirurgene på et lokalsykehus i nedslagsfeltet vårt kjøpte vi i 2011 et lite ultralydapparat for enkel obstetrisk bruk. Sykehuset har ca. 1000 fødsler per år, og kirurgene hadde flere ganger utført sectio ved dødt foster fordi sikker diagnose ikke var stilt på forhånd. Et ultralydapparat ville derfor være til stor nytte i liknende situasjoner.

Da apparatet skulle overleveres, stilte den norske leverandøren spørsmålet som jeg ikke hadde ofret en tanke de åtte årene jeg hadde reist ut og inn av Kambodsja: «Hvordan er det egentlig med strømforsyningen, og er kontaktene jordet?» For en enkel gynekolog var det mye vanskeligere å svare på det spørsmålet enn å håndtere et komplisert pasienttilfelle. Med skam måtte jeg bekjenne at jeg rett og slett ikke ante hvordan det sto til. Overraskelsen ble ikke mindre da mine kambodsjanske kolleger heller ikke kunne svare. Dette ble opptakten til et lite, men viktig sidespor i det medisinske arbeidet Tromsø mineskadesenter driver i landet.

Etter at elektriker Edgar Kalås vinteren 2013 gjennomførte en kartlegging av standarden på utstyr og elektrisk anlegg ved tre av lokalsykehusene som mineskadesenteret samarbeider med, forsto vi at vi bare hadde avdekket toppen av et isfjell. Sykehusene hadde utstyr, men svært mye manglet sikring mot ustabil strøm eller lynnedslag. Det fantes ingen rutiner for vedlikehold, noe som er spesielt viktig i områder med stor fuktighet i regntiden og ekstrem støvmengde i tørre perioder. Vedlikehold og reparasjoner ble utført av leger eller sykepleiere som tilfeldigvis var teknisk interesserte og nevenyttige, og behovet for systematisk opplæring var betydelig. I tillegg var de elektriske anleggene svært kreativt satt opp og stemoderlig ivaretatt.

\section{Nyttig kurs}

I månedene etter kartleggingen fikk vi flere henvendelser fra Kambodsja med forespørsel om vi kunne kjøre et elektrikerkurs for vedlikeholdspersonell. Tromsø mineskadesenters budsjett er stramt, men da begge våre instruktører, Edgar Kalås og Øystein Stene, fikk permisjon med lønn fra sine arbeidsgivere (hhv. NRK-Rana og Helgelandssykehuset), fant vi midler til å kunne gjennomføre et fire dagers grunnkurs i basal strøm- og elektrolære. Kurstilbudet gikk ut til sju lokalsykehus i nordvestre del av Kambodsja, og til sammen 22 deltakere møtte til første kursdag 10. februar 2014. Det viste seg at bare tre av de 22 hadde elektrikeropplæring. De resterende 19 var leger, sykepleiere og jordmødre. Det var

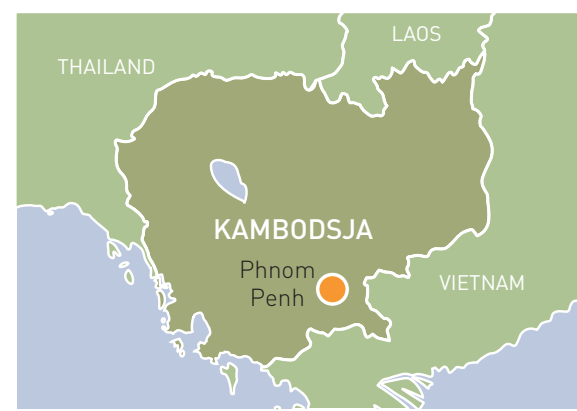

med andre ord en forsamling med svært variert bakgrunn og erfaring, og instruktørene fikk bruk for uante pedagogiske evner. Kurs- og foredragsplanene som var lagt på forhånd måtte forkastes, siden de aller fleste deltakerne manglet helt basal kunnskap om hva elektrisitet egentlig er. Fokuset ble derfor rettet mot praktiske øvelser og det å forstå strøm. Instruktørene demonstrerte sikkerhetsutstyr som hansker og visir, og hvert sykehus fikk enkle multimeter til bruk lokalt. Det ble avholdt en praktisk kursprøve, inkludert basal førstehjelp ved strømulykker, før alle deltakerne fikk kursbevis.

Øystein, som er medisinskteknisk ingeniør, gjorde i tillegg vedlikehold og reparasjoner på utstyr som en del av undervisningen, og sjelden har han opplevd mer entusiastiske assistenter og tilskuere. Det viste seg bl.a. at en defibrillator gitt av en amerikansk organisasjon var designet for 110 volt. Den

Kambodsja (1, 2)

- Kongedømme

- Ca. 14 millioner innbyggere

- På tross av økonomisk vekst lever fremdeles $3 / 4$ av befolkningen under/ like over WHOs fattigdomsgrense, $<2$ USD per dag

- $\emptyset$ kende skille mellom fattige og rike

- Offisiell mødredødelighet 250/100 000 levendefødte

- Svært vanskelige forhold for politisk opposisjon 


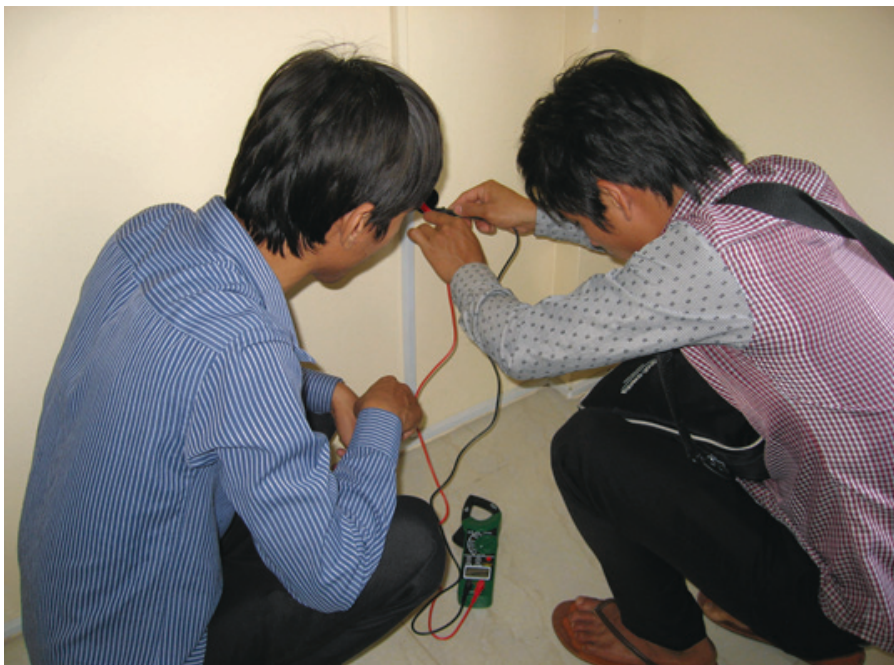

Jord eller ikke jord - det er spørsmålet! Begge foto: Tromsø mineskadesenter

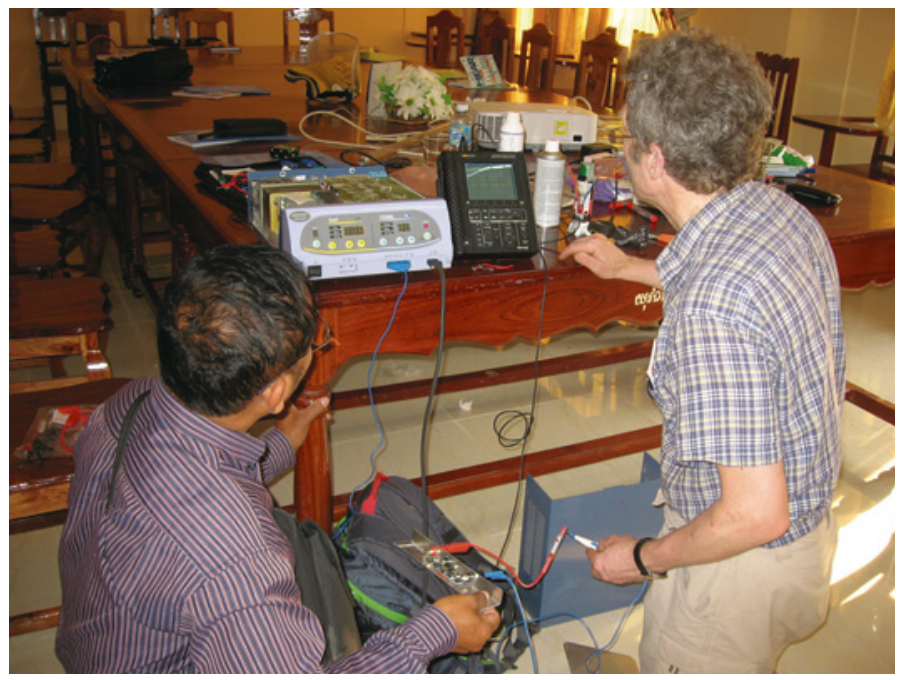

Reparasjon av diatermien fungerte derfor ikke i Kambodsja der man har 220 volt. Øystein bygde om defibrillatoren, til stor jubel for de ansatte på sykehuset.

Den største aha-opplevelsen fikk både instruktører og kursdeltakere da de skulle reparere operasjonslampen på sykehuset der kurset ble holdt. Sykehuset er relativt stort, og standarden på medisinsk behandling er svært god. Kirurgene mente det var feil ved lampen fordi de stadig fikk støt under operasjonene. Det viste seg imidlertid at lampen var helt $i$ orden, men at ingen av kontaktene på operasjonsstuen hadde jording. Med andre ord var alt utstyr, inkludert diatermien, strømførende. Alle kursdeltakerne kjente igjen problemet fra sine sykehus, og vi antar derfor at mangel på jording er et hovedproblem på mange helseinstitusjoner i Kambodsja.

Et av sykehusene som var representert ved kurset ble åpnet vinteren 2013. Sykehuset ligger nord mot grensen til Thailand, og nasjonale myndigheter har lagt mye penger i prosjektet. Den moderne arkitekturen er imidlertid ikke tilpasset lokale forhold. De fleste rommene har ikke vinduer og er dermed avhengig av aircondition, og strøm er svært dyrt i Kambodsja. Ved første regntid ble alt elektrisk utstyr ødelagt etter kraftige lynnedslag. Pasientene måtte flyttes tilbake til de gamle enetasjes bygningene som får lufting gjennom vinduer og sprosser. Reparasjonene ble svært kostbare. Direktøren, som er lege, er bekymret for fremtiden i et bygg som hadde passet fint i California, men ikke i jungelen i Kambodsja.

\section{Konklusjon}

Erfaringene vi gjorde oss noen dager i februar 2014 er neppe enestående for verken Tromsø mineskadesenter eller Kambodsja. Mange av Tidsskriftets lesere har sikkert opplevd tilsvarende $\mathrm{i}$ andre land og regioner.

Norsk helsebistand satser stort på lokal kompetansebygging. I denne sammenhengen har vi forstått at det ikke bare mangler helsepersonell, men kanskje i enda større grad elektrikere og ingeniører. Resultatet er Reodor Felgen-løsninger, som i verste fall kan ta livet av både pasient og behandler. Våre kursdeltakere rapporterte at dette var første gangen de hadde hørt om jording.

Ved planlegging av medisinske bistandsprosjekter bør man også vektlegge grunnleggende infrastruktur som sikker og stabil strømforsyning. Norske håndverkere $\mathrm{og}$ ingeniører har mye å bidra med.

\section{Margit Steinholt (f. 1957)}

er spesialist i fødselshjelp og kvinnesykdommer og er leder for Troms $\varnothing$ mineskadesenter. Forfatter har fylt ut ICMJE-skjemaet og oppgir ingen interessekonflikter.

Litteratur

1. Troms $\varnothing$ mine victim resource center. www.traumacare.no (28.5.2014).

2. Hill H, Menon J. Cambodia: rapid growth with institutional constraints. Asian Development Bank www.adb.org/publications/cambodia-rapidgrowth-weak-institutions (28.5.2014)

3. Husum H, Gilbert M, Wisborg T et al. Rural prehospital trauma systems improve trauma outcome in low-income countries: a prospective study from North Iraq and Cambodia. J Trauma 2003; 54: 1188-96.

4. Husum H. Gilbert M. Wisborg T et al. Land mine injuries: a study of 708 victims in North Iraq and Cambodia. Mil Med 2003; 168: 934-40.

Mottatt 23.4. 2014 og godkjent 29.5. 2014. Redaktør: Erlend Hem. 